\title{
4.4 亿年前全球广布的赫南特贝动物群再添新认识
}

晚奥陶世赫南特贝动物群因其发育在奥陶纪末大灭 绝第一幕之后、第二幕之前，且全球广泛分布，长期受到 国际地学界关注. 华南出露百余条连续完整的奥陶系-志 留系界线剖面, 且壳相和笔石相化石均很丰富, 研究发现 华南是赫南特贝动物群化石最丰富、地理分布最广泛、地 质延限最长、生态分异最复杂的地区. 詹仁斌等人通过详 细研究各代表性剖面中赫南特贝动物群纵向上的多样性变 化, 并综合考察该动物群在整个扬子区横向上的多样性变 化趋势, 对动物群的时空分布规律与华南区域地质构造演 化的关系提出了一些新的认识. 该研究发表在《中国科学: 地球科学》 2010 年第 9 期上.

奥陶纪末的大灭绝事件是显生宙以来发生的规模第 二大的生物集群灭绝事件, 研究它的关键之一就是赫南特 贝动物群, 在国际上具有很高的关注度. 我国学者利用华 南得天独厚的地层古生物资源优势, 已经取得了一系列国 际领先的研究成果，曾先后获得过国家自然科学二等奖 (2008)和江苏省科技进步一等奖(2009). 通过对华南数十 条详细研究的奥陶系-志留系界线剖面进行总结, 发现奥 陶纪末的赫南特贝动物群在华南扬子区的一系列产地中, 从当时的近岸地点至远岸地点其首现层位越来越新, 而且 动物群的延续时限也越来越短, 而动物群的整体多样性却
越来越高. 再从任一条剖面纵向考察赫南特贝动物群的多 样性变化, 发现近岸地点的动物群多样性由高向低演变, 而远岸较深水产地的动物群多样性则由低向高演变(图 1)

结合奥陶纪末、志留纪初华南区域地质构造的演变, 研究者发现赫南特贝动物群多样性的纵、横变化与华南当 时的古地理变迁是密切相关的. 赫南特贝动物群是一个典 型的正常浅海底栖壳相动物群. 晚奥陶世赫南特期早期, 即赫南特贝动物群发育的早期, 华南扬子区那些相对近岸 的地点的底域环境正好适合赫南特贝动物群的繁衍, 而此 时的远岸地点, 由于水体过深而不适宜赫南特贝动物群生 存; 后来, 随着华夏古陆的快速西扩, 整个扬子区的海水 变浅, 那些适宜赫南特贝动物群生存的近岸地点由于水体 进一步变浅而不再适宜动物群繁衍, 而那些原先的远岸较 深水地区则由于水体变浅正好适宜动物群繁衍, 而且, 经 过一段时间的演化准备，到赫南特期中后期，赫南特贝动 物群进入了它的宏演化繁盛期, 这就是远岸较深水地点的 总体多样性要远高于近岸地点的缘故. 研究还发现, 随地 点和层位而发生的环境因子的变化(如水深、底质等), 赫南 特贝动物群在华南还应对以不同的群落、亚群落或群集.

所有这些新认识, 充分说明了生物与环境存在密不可分 的协同演变关系, 即便在大灭绝事件发生的过程中也不例外.

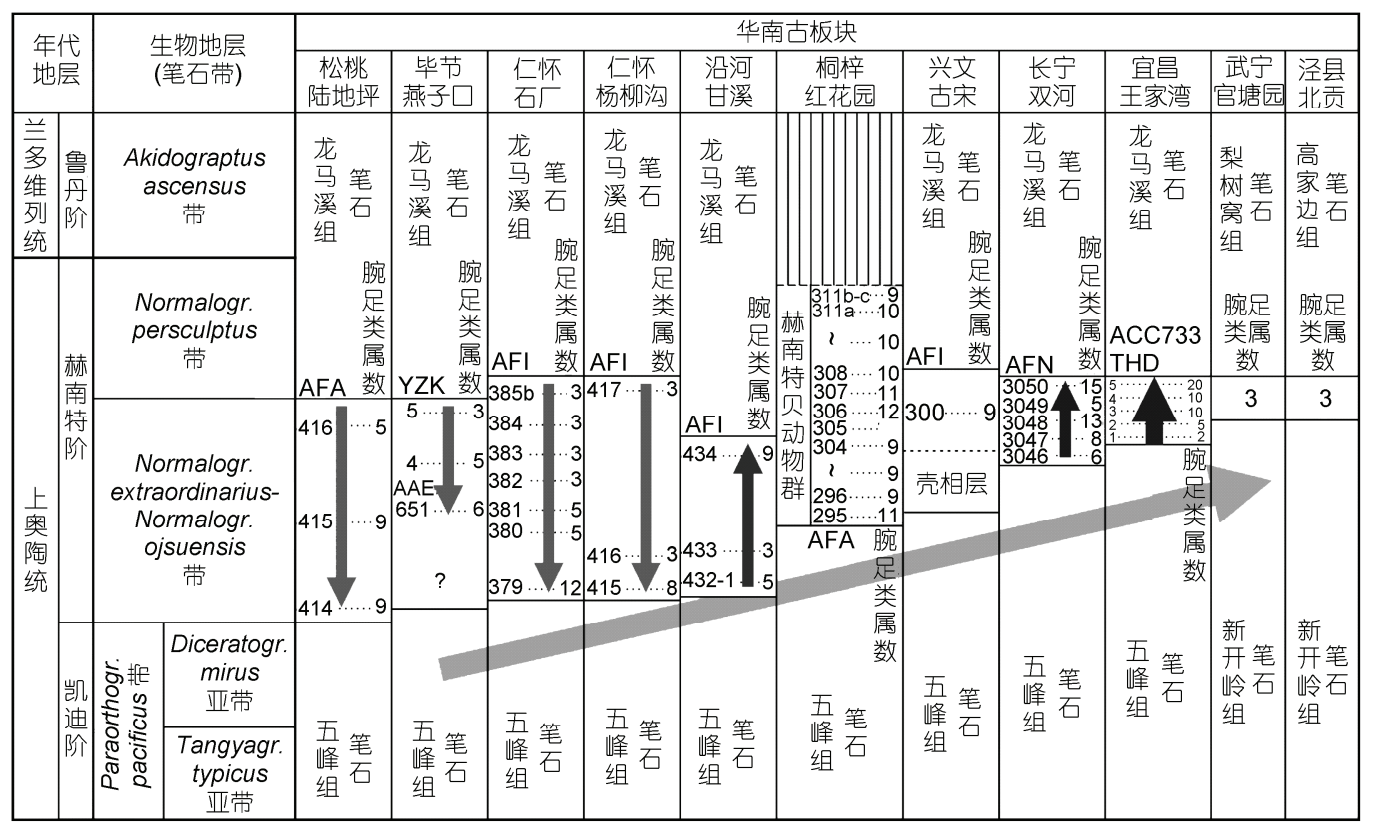

图 1 华南赫南特贝动物群从近岸浅水地点(如贵州松桃陆地坪)至远岸较深水地点(如安徽泾县北贡) 多样性的纵向和横向变化(詹仁斌等, 2010) 